\title{
PENGARUH TERAPI BERMAIN (MEWARNAI) TERHADAP TINGKAT STRES PADA ANAK USIA SEKOLAH YANG MENJALANI PHYSICAL DISTANCING DI RW 03 KELURAHAN KEDUNGDORO TEGALSARI SURABAYA
}

\author{
Galuh Permatasari, Dwi Ernawati, Sapto Dwi Anggoro \\ Sekolah Tinggi Ilmu Kesehatan Hang Tuah Surabaya \\ Email: dwiernawati@stikeshangtuah-sby.ac.id
}

\begin{abstract}
Physical distancing is an action that used to stop the spread of covid-19 desease. Nowadays, the Physical distancing which is done have the impact of the children psychology problems such as stress. The purposeof this researchto examine the influence of coloring play therapy toward children's stress levels in a school age who is through the physical distancing at RW 03, kedungdoro village, Tegal sari districts, Surabaya city. The type of research was using quasy-eksperimental method with pre testpost control group design approach. The number of samples on this researchwere 52 children of school age and divided into 26 respondents into theintervention group and 26 respondents into the control group, by using simple random sampling techniques and questionnaire as a measuring instrument. The data analysis was using Mann Whitney and Wilcoxon Signed Rank Test.The result of this research showed that $p$ value $0,001(p<0,05)$ had an influenced of coloring play theraphy toward children's stress levelin a school age who was through physical distancing at RW 03, kedungdorovillage, Tegal sari districts, Surabaya city. The implications of this research was to reduced stress in a school age who wasthrough physical distancing by doing the coloring play therapy everyday during 20-30 minutes in a free time.
\end{abstract}

\section{Keyword: Physical Distancing, Play Therapy, Stress, School Age Children}

\begin{abstract}
Abstrak: Physical distancing adalah suatu istilah tindakan yang digunakan untuk menghentikan atau memperlambat penyebaran penyakit menular seperti Covid-19. Physical distancing yang dilakukan saat ini dapat berdampak pada masalah psikologis anak seperti stres. Salah satu cara untuk mengurangi stress adalah dengan terapi bermain mewarnai. Penelitian ini bertujuan untuk meneliti pengaruh terapi bermain mewarnai terhadap tingkat stres anak usia sekolah yang menjalani physical distancing di RW 03 Kelurahan Kedungdoro Kecamatan Tegalsari Surabaya. Jenis penelitian ini menggunakan metode Quasy-Eksperimental dengan pendekatan Pre Test-Post Test Control Group Design. Sampel penelitian ini berjumlah 52 anak usia sekolah dibagi menjadi 26 responden dalam kelompok intervensi, dan 26 responden dalam kelompok kontrol, dengan menggunakan teknik Simple Random Sampling dan alat ukur tingkat stres yang digunakan adalah kuesioner. Analisa data menggunakan Mann Whitney dan Wilcoxon Signed Rank Test. Hasil penelitian menunjukkan bahwa $p$ value $0,001(p<0,05)$ yang berarti ada pengaruh terapi bermain mewarnai terhadap tingkat stress anak usia sekolah yang menjalani physical distancing di RW 03 Kelurahan Kedungdoro Kecamatan Tegalsari Surabaya Implikasi penelitian ini adalah untuk menurunkan stress pada anak usia sekolah yang menjalani physical distancing dengan melakukan terapi bermain mewarnai setiap hari selama 20-30 menit di waktu senggang.
\end{abstract}

Kata Kunci: Physical distancing, Terapi Bermain, Stres, Anak Usia Sekolah

\section{PENDAHULUAN}

Manusia adalah makhluk holistik dan tidak dapat hidup tanpa bersosialisasi dengan orang lain. Setiap orang tua senantiasa selalu mengajarkan pada anaknya untuk bersosialisasi dengan orang lain dan salah satu cara bentuk sosialisasi menurut anak adalah dengan bermain bersama teman-temannya khususnya untuk anak usia sekolah. Tetapi pada kondisi sekarang, dimana suatu peristiwa yang menyebabkan manusia sementara diharapkan untuk menjaga jarak secara fisik dengan orang lain yang disebut dengan Physical Distancing. Fenomena Covid-19 yang terjadi membuat pemerintah memberlakukan physical distancing untuk memutus penyebaran Covid-19. Anak-anak yang selalu berada di luar rumah baik untuk kegiatan sekolah atau kegiatan yang lain seperti bermain, sekarang harus tetap berada di rumah dan banyak dari mereka yang mengeluh bosan dan ingin keluar rumah bertemu dengan teman-temannya. Selain itu, selama pandemi Covid-19 para guru yang mengajar di setiap sekolah harus menyiapkan beberapa kegiatan untuk anak didiknya selama berada di rumah. Salah satunya adalah saat berada di rumah, guru 
memberi banyak tugas secara online. Stres yang dialami oleh anak selama pandemi ini memiliki beberapa dampak. Dampak dari stres salah satunya adalah menurunnya sistem kekebalan tubuh pada tubuh anak. Jika sistem kekebalan tubuh anak turun, maka tubuh akan sulit menangkal virus atau bakteri yang dapat membuat anak tersebut sakit. Respon anak-anak yang mengalami stres biasanya di tunjukkan dengan terganggunya sistem pencernaan, kelelahan, sakit kepala dan gangguan tidur (Catootjie, 2009).

Data statistik tentang anak stres akibat Covid-19 menurut WHO (World Health Organization) terdapat 136 negara telah terjangkit virus Covid-19 dengan 23.335 jiwa yang meninggal sampai dengan tanggal 27 Maret 2020. Menurut Aliansi Pelajar Surabaya (APS) menyatakan bahwa 16.000 anak usia sekolah di Jawa timur mengalami stres selama masa Covid-19. Studi pendahuluan yang dilakukan dengan menanyakan kepada orang tua masingmasing anak menunjukkan bahwa 40 orang anak usia sekolah yang menjalani physical distancing mengalami stres dengan presentase $70 \%$ dari populasi anak yang berada di kelas 1 dari beberapa sekolah dasar yang berada di RW 03 Kelurahan Kedungdoro Kecamatan Tegalsari Surabaya.

Stres yang dialami oleh anak selama pandemi ini memiliki beberapa dampak. Dampak dari stres salah satunya adalah menurunnya sistem kekebalan tubuh pada

\section{METODE PENELITIAN}

Penelitian ini menggunakan desain Quasy-eksperimental dengan pendekatan Pre Test-Post Test Control Group Design dengan menggunakan Simple Random Sampling. Variabel pada penelitian ini adalah tingkat stres pada anak yang menjalani Physical Distancing. Sampel dalam penelitian ada 52 siswa-siswi kelas I

\section{HASIL PENELITIAN}

Hasil penelitian berdasarkan jenis kelamin pada tabel 1. Pada kelompok intervensi mendapatkan sebagian besar responden adalah laki-laki sejumlah 15 orang $(58 \%)$ dan perempuan sejumlah 11 orang (42\%), pada kelompok kontrol tubuh anak. Jika sistem kekebalan tubuh anak turun, maka tubuh akan sulit menangkal virus atau bakteri yang dapat membuat anak tersebut sakit. Respon anakanak yang mengalami stres biasanya di tunjukkan dengan terganggunya sistem pencernaan, kelelahan, sakit kepala dan gangguan tidur (Catootjie, 2009).

Stres pada anak yang menjalani physical distancing dapat dilakukan beberapa terappopp[i yang dapat dilakukan oleh orang tua di dalam rumah. Terapi tersebut seperti terapi bermain puzzle, terapi bermain origami, terapi bermain dengan media audiovisual dan terapi bermain dengan media menggambar dan mewarnai. Salah satu jenis terapi bermain yang bisa dilakukan adalah dengan mewarnai. Selain karena alat yang mudah didapat dan murah, banyak anak-anak yang mengekspresikan perasaannya melalui mewarnai. Terapi bermain mewarnai memiliki beberapa fungsi. Mewarnai berfungsi untuk membantu meringankan stres pada anak karena warna dapat digunakan untuk menggambarkan emosi seseorang(Rahayu, 2018).Karena amigdala dalam sistem limbik di dalam otak dapat membantu mengekspresikan perasaan dan membangkitkan memori yang tersimpan dalam otak tengah (thalamus) sehingga emosi dan perasaan dapat dikeluarkan dan menciptakan koping yang positif yang didapat melalui mewarnai gambar (Aizah and Wati, 2014).

yang menjalani Physical Distancing dengan mengisi kuesioner menggunakan google form tingkat stres Analisis uji yang digunakan adalah Wilcoxon Signed Rank Test dan Mann Whitney. Penelitian ini dilakukan di RW 03 Kelurahan Kedungdoro Kecamatan Tegalsari Surabaya.

mendapatkan 18 orang (70\%) perempuan, dan 8 orang $(30 \%)$ laki-laki.

Hasil dari penelitian pada kelompok intervensi mendapatkan hasil bahwa jenis kelamin dapat mempengaruhi stres berat. Faktor yang berdasarkan jenis kelamin 
pada 14 responden (27\%) adalah laki-laki yang paling banyak mengalami stres berat. Penelitian ini sesuai dengan teori Kartono (2010) bahwa pada umur sekolah, anak laki-laki sering stres daripada anak perempuan (Kartono, 2010). Peneliti berpendapat bahwa stres dapat dipengaruhi oleh jenis kelamin. Laki-laki cenderung mudah mengalami stres karenakarena hormon testoteron yang diproduksi juga dapat menghasilkan zat kimia yaitu kortisol. Kortisol ini akan mempengaruhi lobus frontal pada otak dan menyebabkan stres (Kupriyanov, R., Zhdanov, 2014). Sehingga proses stres yang terjadi dirasakan lebih berat oleh anak laki-laki daripada perempuan karena stres pada laki-laki mengarah ke perilaku yang akan ditunjukkan seperti menjadi lebih agresif sedangkan perempuan akan mengarah ke emosionalnya.

Tabel 2. karakteristik berdasarkan lama kegiatan di luar rumah di RW 03 Kelurahan Kedungdoro Kecamatan Tegalsari Surabaya $(\mathrm{N}=52)$

\begin{tabular}{ccccc}
\hline Lama Kegiatan di Luar Rumah & \multicolumn{2}{c}{ Kelompok Intervensi } & \multicolumn{2}{c}{ Kelompok Kontrol } \\
\hline & $\mathrm{N}$ & $(\%)$ & $\mathrm{N}$ & $(\%)$ \\
6-7 jam/hari & 5 & 19 & 10 & 39 \\
$7-8$ jam/hari & 9 & 35 & 10 & 39 \\
8-9 jam/hari & 12 & 46 & 6 & 22 \\
\hline Total & 26 & 100 & 26 & 100 \\
\hline
\end{tabular}

Hasil penelitian berdasarkan tabel 2. lama kegiatan di luar rumah menunjukkan bahwa responden yang melakukan kegiatan di luar rumah bervariasi intensitasnya. Sebanyak 12 orang (46\%) melakukan kegiatan diluar rumah selama 8-9 jam setiap harinya. sedangkan sebanyak 9 responden (35\%) melakukan kegiatan di luar rumah selama 7-8 jam setiap harinya. Sementara 5 responden (19\%) melakukan kegiatan di luar rumah selama 6-7 jam setiap harinya. dengan demikian sebagian besar responden beraktivitas sangat intensif di luar rumah. Sedangkan pada kelompok kontrol juga memiliki kegiatan di luar rumah yang bervariasi juga. Pada kelompok kontrol sebanyak 6 responden (22\%) melakukan kegiatan di luar rumah selama 8-9 jam setiap harinya. Sedangkan sebanyak 10 responden (39\%) melakukan kegiatan di luar rumah selama 7-8 jam setiap harinya. Lalu sebanyak 10 responden $(39 \%)$ melakukan kegiatan di luar rumah selama 6-7 jam setiap harinya.
Stres berat yang dialami responden dalam kelompok intervensi juga dapat dipengaruhi oleh faktor lama mereka di luar rumah. Hasil penelitian mendapatkan sebanyak 9 responden (17\%) dari 14 responden yang mengalami stres berat menjawab bahwa mereka selalu menghabiskan waktu bersama temantemannya selama 8-9 jam setiap harinya pada kuesioner yang telah diberikan. Dalam teori Meiliani, Nandang dan Nunung (2018) menyatakan bahwa keberadaan teman sebaya dapat membantu seseorang untuk membentuk kepribadian dan lingkungan sosial yang ada di dalamnya mampu membuat anak-anak merasa nyaman (Suharto, Mulyana and Nurwati, 2018). Peneliti berpendapat faktor lingkungan seperti teman sebaya sangat berpengaruh pada stres yang dialami karena semakin lama seorang anak berada di luar rumah akan membuat dirinya merasa diterima oleh lingkungan sekitarnya.

Tabel 3. karakteristik berdasarkan jumlah saudara di RW 03 Kelurahan Kedungdoro Kecamatan Tegalsari Surabaya $(\mathrm{N}=52)$

\begin{tabular}{lcccc}
\hline \multicolumn{1}{c}{ Jumlah Saudara } & \multicolumn{2}{c}{ Kelompok Intervensi } & \multicolumn{2}{c}{ Kelompok Kontrol } \\
\hline & $\mathrm{N}$ & $(\%)$ & $\mathrm{N}$ & $(\%)$ \\
Tunggal & 11 & 43 & 3 & 11 \\
2 Bersaudara & 9 & 35 & 7 & 27 \\
3 Bersaudara & 3 & 11 & 6 & 23 \\
$>$ 3 Bersaudara & 3 & 11 & 10 & 39 \\
\hline Total & 26 & 100 & 26 & 100 \\
\hline
\end{tabular}


Hasil penelitian berdasarkan jumlah saudara menunjukkan bahwa responden yang sebagian besar memiliki saudara. Sebanyak 11 responden (43\%) pada kelompok intervensi adalah anak tunggal. Sedangkan 9 responden (35\%) adalah anak dengan satu saudara ( 2 bersaudara). Lalu 3 responden (11\%) adalah anak dengan dua saudara (3 bersaudara) dan 3 responden lainnya (11\%) adalah anak dengan lebih dari dua saudara ( $>3$ bersaudara). Sedangkan di kelompok kontrol mendapatkan sebanyak 3 responden (11\%) adalah anak tunggal. 7 responden $(27 \%)$ adalah anak yang memiliki satu saudara ( 2 bersaudara). 6 responden (23\%) adalah anak dengan dua saudara ( 3 bersaudara) dan 10 responden (39\%) adalah anak dengan lebih dari dua saudara ( $>3$ bersaudara).

Hasil penelitian pada tabel jumlah saudara ini dapat diketahui bahwa jumlah saudara yang responden pada kelompok intervensi miliki dapat berpengaruh dengan kejadian stres berat yang dialami oleh anak. Sebanyak 11 anak (21\%) yang mengalami stres berat merupakan anak tunggal di dalam keluarga mereka, sehingga mereka tidak memiliki teman saat berada di rumah sehingga 11 responden menjawab selalu kesepian pada poin pertanyaan tujuh pada kuesioner yang diberikan. Hasil penelitian ini sepemikiran dengan teori Marc Jambon (2018) yang mengatakan bahwa pengaruh saudara dapat membuat anak akan tumbuh menjadi kepribadian dengan koping positif karena saudara adalah guru dan model peran yang lebih efektif untuk perkembangan koping anak (Jambon, 2018). Penelitian yang dilakukan oleh Dwi Ernawati (2019) sama dengan teori Marc Jambon yang menyatakan bahwa anak yang berada di usia sekolah akan lebih aktif dan cenderung mempunyai tingkah laku yang berhubungan dengan kecemburuan, pertengkaran serta konflik antar saudara(Diyah Arini, Dwi Ernawati, Dini Mei Widayanti 2019).Maka peneliti berpendapat bahwa jumlah saudara yang dimiliki oleh responden dapat berpengaruh dengan stres yang dialami karena dengan adanya saudara di dalam rumah dan termasuk dalam keluarga besar yang berada dalam satu rumah, ia tidak akan merasa sendiri dan kesepian sehingga ia akan lebih nyaman saat berada di rumah. Kecuali jika anak hanya terdiri dari ayah, ibu dan satu saudara bahkan tunggal akan dapat berpengaruh dalam tingkatstres yang dialami oleh anak tersebut.

Tabel 4. Tingkat Stres Pada Anak Usia Sekolah Yang Menjalani Physical Distancingsebelum dilakukan intervensi di RW 03 Kelurahan Kedungdoro Kecamatan Tegalsari Surabaya

\begin{tabular}{llcccc}
\hline No & Tingkat Stres Responden & \multicolumn{2}{c}{ Kelompok Intervensi } & \multicolumn{2}{c}{ Kelompok Kontrol } \\
\hline & & $\mathrm{N}$ & $(\%)$ & $\mathrm{N}$ & $(\%)$ \\
\cline { 2 - 6 } 1. & Stres Sangat Berat & - & - & - & - \\
2. & Stres Berat & 14 & 54 & - & - \\
3. & Stres Sedang & 12 & 46 & 17 & 65 \\
4. & Stres Ringan & - & - & 9 & 35 \\
5. & Normal & - & - & - & - \\
\hline & Total & 26 & 100 & 26 & 100 \\
\hline
\end{tabular}

Hasil penelitian berdasarkan tingkat stres sebelum intervensi menunjukkan bahwa responden mmeiliki tingkat stres yang berbeda-beda sebelum dilakukan terapi bermain mewarnai. Pada kelompok intervensi mendapatkan hasil tingkat stres berat sebanyak 14 orang (54\%) dan stres sedang sebanyak 12 orang (46\%). Sedangkan untuk kelompok kontrol mendapatkan hasil tingkat stres sedang sebanyak 17 orang $(65 \%)$ dan stres ringan sebanyak 9 orang (35\%). 
Tabel 5. Tingkat Stres Pada Anak Usia Sekolah Yang Menjalani Physical Distancingsetelah dilakukan intervensi di RW 03 Kelurahan Kedungdoro Kecamatan Tegalsari Surabaya

\begin{tabular}{llcccc}
\hline No & \multicolumn{1}{c}{ Stres Responden } & \multicolumn{2}{c}{ Kelompok Intervensi } & \multicolumn{2}{c}{ Kelompok Kontrol } \\
\cline { 3 - 6 } & & $\mathrm{N}$ & $(\%)$ & $\mathrm{N}$ & $(\%)$ \\
1. & Stres Sangat Berat & - & - & - & - \\
2. & Stres Berat & - & - & - & - \\
3. & Stres Sedang & 14 & 54 & 17 & 65 \\
4. & Stres Ringan & 12 & 46 & 9 & 35 \\
5. & Normal & - & - & - & - \\
\hline & Total & 26 & 100 & 26 & 100 \\
\hline
\end{tabular}

Hasil penelitian berdasarkan tingkat stres sesudah intervensi menunjukkan bahwa ada perubahan tingkat stres setelah dilakukan terapi bermain mewarnai. Pada kelompok intervensi mendapatkan perubahan tingkat stres. Sebanyak 14 responden (54\%) yang sebelumnya mengalami stres berat menjadi stres sedang. Lalu sebanyak 12 responden $(46 \%)$ yang sebelumnya mengalami stres sedang menjadi stres ringan. Sedangkan pada kelompok kontrol tidak ada perubahan dengan sebanyak 17 responden (65\%) mengalami stres sedang dan 9 responden $(35 \%)$ stres yang ringan.

Stres yang dialami oleh anak yang berusia sekolah selama menjalani physical distancing mengalami perubahan sesudah

\section{PEMBAHASAN}

Stres yang dialami oleh anak-anak tidak semata-mata langsung terjadi tetapi ada stressor yang mempengaruhi. Stressor yang dialami akan masuk ke dalam otak dapat mempengaruhi sistem kerja saraf manusia yaitu hipotalamus. Hipotalamus berfungsi untuk mengontrol dan mengatur sistem saraf otonom. Pada kondisi stres, sistem saraf akan mengeluarkan hormon norrepineprin yang dapat meningkatkan tekanan darah sehingga saat tekanan darah meningkat kita akan menjadi stres (Bare, 2013).

Terapi bermain (mewarnai), anakanak dapat menuangkan perasaannya dengan coretan dan pemilihan warna. Seseorang akan mengeluarkan muatan negatif yang ada di dalam amigdalanya seperti sedih, tertekan, dan stres lalu digantikan oleh hormon oksitosin yang dihasilkan dari sekresi hipotalamus dapat membuat suasana hati kembali senang. Terapi bermain dapat juga dijadikan relaksasi yang dapat menurunkan aktifitas sistem saraf simpatis sehingga arteri diberikan terapi bermain mewarnai. Dimana pada kelompok intervensi, sebanyak 14 anak (54\%) yang mengalami stres berat sebelum diberikan terapi bermain mewarnai, semuanya mengalami perubahan menjadi stres sedang, kemudian 12 anak (46\%) yang mengalami stres sedang mengalami perubahan menjadi stres ringan. Perubahan ini menunjukkan bahwa terapi bermain mewarnai dapat mempengaruhi tingkat stres anak yang sedang menjalani physical distancing. Hasil dari uji Wilcoxon Signed diperoleh bahwa terapi bermain dapat berpengaruh terhadap tingkat stres pada anak yang berusia sekolah yang menjalani physical distancing di RW 03 Kelurahan Kedungdoro Kecamatan Tegalsari Surabaya.

melebar dan peredaran darah lancar yang kemudian darah yang mengandung banyak oksigen dapat mengalir ke seluruh jaringan terutama ke perifer sehingga rasa khawatir dan stres dapat berkurang. Dengan mewarnai gambar, emosi dan perasaan anak-anak tersebu dapat keluar sehingga stres berkurang (Hidayah, 2011).

Peneliti berasumsi dari penjelasan diatas, hal ini membuktikan bahwa hasil dari keseluruhan responden yang mengalami stres berat atau stres sedang dapat tertangani dengan baik melalui terapi bermain mewarnai ini. 14 reponden yang sebelumnya mengalami stres berat berubah secara perlahan menjadi stres sedang, sedangkan 12 responden yang mengalami stres sedang juga mengalami perubahan stres dari sedang ke ringan. Masyarakat juga berasumsi tentang stres yang dialami oleh anak-anak yang menjalani physical distancing adalah salah satu kejadian yang dapat mengganggu tumbuh kembang sang anak. Dalam teori Kupriyanov dan Zhdanov (2014) menyatakan bahwa anak yang 
mengalami stres bisa berdampak pada kondisi fisik dan mentalnya (Kupriyanov, R., Zhdanov, 2014). Selama penelitian yang dibantu oleh orang tua sebagai mitra peneliti, responden mengatakan bahwa dirinya selalu mengeluh bosan/jenuh kepada orang tua, merasa kesepian dan kadang sulit untuk tidur serta nafsu makan berkurang. Maka dari itu, peneliti bekerja sama dengan orang tua untuk melakukan terapi bermain mewarnai yang bertujuan untuk mengurangi stres pada anak sehingga anak memiliki koping yang positif.

Perubahan yang terjadi pada responden yang sebelumnya mengalami stres berat lalu berubah menjadi stres sedang karena responden mulai mampu menerima keadaan yang mengharuskan mereka tinggal di dalam rumah. Koping

\section{KESIMPULAN DAN SARAN}

Terapi bermain mewarnai yang dilakukan ini dapat menurunkan tingkat stress pada anak yang sedang menjalani physical distancing di RW 03 Kelurahan Kedungdoro Kecamatan Tegalsari Surabaya dengan melakukan terapi selama sepuluh hari dengan 1 hari 20-30 menit.

Saran bagi orang tua yaitu, orang tua bisa melakukan terapi bermain mewarnai ini untuk membantu mengurangi kejenuhan sang anak sehingga anak tidak mengalami stres. Bagi STIKES Hang Tuah Surabaya penelitian ini diharapkan dapat berguna atau dapat dijadikan masukan

\section{DAFTAR PUSTAKA}

Adriana (2013) tumbuh kembang dan terapi bermain anak. Jakarta: Salemba Medika

Aizah, S. and Wati, S. E. (2014) 'Upaya Menurunkan Tingkat Stres Hospitalisasi Dengan Aktifitas Mewarnai Gambar pada Anak Usia 46 Tahun di Ruang Anggrek RSUD Gambiran Kedin', Ejornal Kedokteran Universitas Airlangga, 25(1), pp. 610.

Alligood, M. (2017) Pakar Teori Keperawatan dan Karya IImiah Edisi Indonesia. 8th edn. jakarta: elsesiver.

Blackwell, W. (2019) 'Coronavirus Disease 2019', tropical medicine \& international helath, (covid-19). positif mulai terlihat setelah tiga kali terapi dengan di dampingi orang tua masingmasing. Proses dalam terapi bermain mewarnai mampu membuat anak-anak merasa relaks dan perhatian akan hal tidak menyenangkan teralihkan. Otak yang sebelumnya memuat emosi negatif berubah menjadi positif berkat coretan dan warna yang pilih oleh anak-anak tersebut (Fariz, 2009).

Terapi bermain tepat diberikan untuk anak yang mengalami stres dan terapi bermain adalah metode mudah untuk mengalihkan anak dari sesuatu yang dapat membuat mereka stres. Dari pembahasan dapat di simpulkan bahwa terapi bermain mewarnai ada pengaruh terhadap tingkat stres pada anak yang sedang menjalani physical distancing.

dalam upaya meningkatkan mutu pembelajaran tentang keperawatan anak untuk kemajuan profesi keperawatan.

Kondisi pandemik seperti ini, diharapkan masyarakat mampu mempraktekkan dan membagi wawasan tentang pentingnya mencegah stress pada anak dengan masyarakat yang lain agar stres yang dialami anak-anak dapat dicegah. Bagi peneliti selanjutnya menambahkan variabel psikologis dengan jumlah responden yang lebih beragam seperti usia dan masalah psikologis lainnya.

Catootjie (2009) 'Stres pada anak: gejala, penyebab, dampak dan penanggulannya'.

Diyah Arini, Dwi Ernawati, Dini Mei Widayanti, Dwi Oktaviana Widyaningrum. 2019. "Hubungan Tipe Kepribadian Dengan Reaksi Sibling Rivalry Pada Anak Prasekolah Usia 35 Tahun." Jurnal Ners LENTERA 7(1): $1-13$

Fariz (2009) 'Manfaat belajar Menggambar dan Mewarnai Bagi Anak', in. jakarta, p. 14.

Hidayah (2011) 'Terapi Bermain: Mewarnai Gambar', 1, p. 2. Available at: .http//.www.umul_hidayah.

Hidayat (2012) 'Pengantar ilmu keperawatan anak (buku l)'. Jakarta: Salemba Medika 
HJambon, M. (2018) 'Hubungan dengan Saudara Kandung Tentukan Kepribadian Anak, Toronto University, February. Available at: https://www.suara.com/health/2018/02 /21/140858/studi-hubungan-dengansaudara-kandung-tentukankepribadian-anak.

Jannah, N. I. (2016) 'Gambaran Tingkat Stres Pada Anak Usia Sekolah dengan Hospitalisasi di RSUD Labuang Baji.

Kartono (2010) 'Patologi Sosial Gangguan Jiwa'. Jakarta: Grafindo Perkasa

Kupriyanov, R., Zhdanov, R. (2014) 'The eustress concept: Problems and outlooks. World Journal of Medical Sciences', pp. 179-185. (Accessed: 27 March 2020).

Nadhifati, L. (2018) 'terapi bermain untuk menurunkan stres hospitalisasi pada pasien anak usia prasekolah', (1), pp. 430-439.

Notoadmojo, S. (2012) Metodelogi Penelitian Kesehatan. Jakarta: Rineka Cipta.

Nursalam (2013) 'Metodologi Penelitian IImu Keperawatan: Pendekatan Praktis, Edisi 3'.

Potter, P. A. dan Perry, A. G. (2015) Buku Ajar Fundamental Keperawatan: Konsep, Proses, dan Praktik. 4th edn. jakarta.

Pranadji, D. K. and Nurlaela, N. (2009) "'Faktor-faktor yang Mempengaruhi Tingkat Stres pada Anak Usia Sekolah Dasar yang Sibuk dan Tidak Sibuk", Jurnal IImu Keluarga dan Konsumen, 2(1), pp. 57-63. doi: 10.24156/jikk.2009.2.1.57.
Purwati, D. (2017) 'pengaruh pemberian terapi bermain mewarnai terhadap tingkat kecemasan pada anak usia sekolah yang hospitalisasi di RSUD Kota Madiun', pp. 1-14.

Rahayu, faridah sri (2018) Penerapan Terapi Bermain Puzzle Terhadap Tingkat Kecemasan Pada Hospitalisasi Anak Usia Prasekolah Di Bangsal Dahlia RSUD Wonosari.

Saputro, H. and Fazrin, I. (2017) Buku Ajar Terapi Bermain di Rumah Sakit. dalam Jurnal Konseling Indonesia Vol. 3 No. 1 (2017). http://ejournal.unikama.ac.id/index.ph $\mathrm{p} / \mathrm{JKI}$

Septiani, R. (2018) 'Hubungan Penerapan Atraumatic Care Dengan Tingkat Stres Saat Hospitalisasi Pada Anak Usia Sekolah'.

Sugiyono (2014) 'Metode Penelitian Kuantitatif, Kualitatif dan $R \& D$ '. Bandung: Alfabeta'

Suharto, M. P., Mulyana, N. and Nurwati, N. (2018) 'Pengaruh Teman Sebaya Terhadap Perkembangan Psikososial Anak Tki Di Kabupaten Indramayu', Focus: Jurnal Pekerjaan Sosial, 1(2), p. $135 . \quad$ doi: 10.24198/focus.v1i2.18278.

Supartini (2004) 'Buku Ajar Konsep Dasar keperawatan Anak'. Jakarta:ECG

Suriadi and Rita (2010) 'asuhan keperawatan pada anak'. Jakarta: Agung Setia.

Yusuf, S. (2004) 'Psikologi Perkembangan Anak \& Remaja'. Bandung: PT. Remaja Rosdakarya 